CALIFORNIA DREAMING 

SUZANNE M. WILSON

\section{California Dreaming}

REFORMING MATHEMATICS EDUCATION 
Copyright (C) 2003 by Suzanne M. Wilson. All rights reserved. This book may not be reproduced, in whole or in part, including illustrations, in any form (beyond that copying permitted by Sections IO7 and Io8 of the U.S. Copyright Law and except by reviewers for the public press), without written permission from the publishers.

Designed by Rebecca Gibb. Set in Scala type by Integrated Publishing Solutions. Printed in the United States of America by Vail-Ballou Press, Binghamton, New York.

Library of Congress Cataloging-in-Publication Data

Wilson, Suzanne M., 1955-

California Dreaming : reforming mathematics education / Suzanne M.

Wilson.

p. $\quad \mathrm{cm}$.

Includes bibliographical references and index.

ISBN 0-300-09432-9 (cloth : alk. paper)

I. Mathematics - Study and teaching - California - History - 2oth century.

2. Educational change-California-History-2oth century. I. Title.

QAi3.5.C2 W57 2003

$510^{\prime} .7 I^{\prime} 097940904-\mathrm{dc} 2 \mathrm{I}$

2002007031

A catalogue record for this book is available from the British Library.

The paper in this book meets the guidelines for permanence and durability of the Committee on Production Guidelines for Book Longevity of the Council on Library Resources.

I0 98765432 I 
To my mother, and her mother

Three little fishies and a mommy fishy, too 
